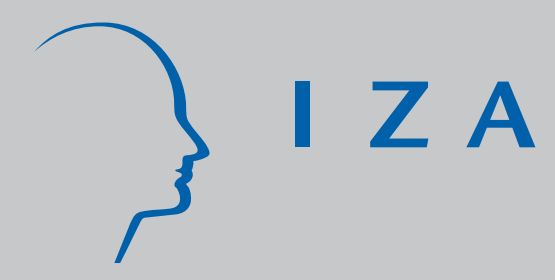

IZADP No. 1622

Dynamic Monopsony:

Evidence from a French Establishment Panel

Fathi Fakhfakh

Felix FitzRoy

J une 2005 


\title{
Dynamic Monopsony: \\ Evidence from a French \\ Establishment Panel
}

\author{
Fathi Fakhfakh \\ Université Paris II, ERMES
}

Felix FitzRoy

University of St. Andrews

and IZA Bonn

\section{Discussion Paper No. 1622 \\ June 2005}

IZA
P.O. Box 7240
53072 Bonn
Germany

Phone: +49-228-3894-0

Fax: +49-228-3894-180

Email: iza@iza.org

\begin{abstract}
Any opinions expressed here are those of the author(s) and not those of the institute. Research disseminated by IZA may include views on policy, but the institute itself takes no institutional policy positions.
\end{abstract}

The Institute for the Study of Labor (IZA) in Bonn is a local and virtual international research center and a place of communication between science, politics and business. IZA is an independent nonprofit company supported by Deutsche Post World Net. The center is associated with the University of Bonn and offers a stimulating research environment through its research networks, research support, and visitors and doctoral programs. IZA engages in (i) original and internationally competitive research in all fields of labor economics, (ii) development of policy concepts, and (iii) dissemination of research results and concepts to the interested public.

IZA Discussion Papers often represent preliminary work and are circulated to encourage discussion. Citation of such a paper should account for its provisional character. A revised version may be available directly from the author. 


\section{ABSTRACT \\ Dynamic Monopsony: Evidence from a French Establishment Panel ${ }^{*}$}

This paper uses a panel of about 6000 French establishments to test some implications of the modern theory of dynamic monopsony or upward sloping labour supply curves for average firm wages. Panel estimates provide strong evidence of a much larger long run employer size - wage effect (ESWE) than found previously, while controlling for worker quality and compensating differentials with lagged wages, and for profitability (rent sharing). Employment expansion also has a positive effect on wages, providing further evidence for upward sloping labour supply (as distinct from the effect of shocks in a perfectly competitive labour market).

JEL Classification: $\quad \mathrm{C} 23, \mathrm{~J} 30, \mathrm{~J} 31$

Keywords: labour supply, dynamic monopsony, firm-size wage effect

Corresponding author:

Felix R. FitzRoy

Department of Economics

University of St. Andrews

St. Andrews

Fife KY16 9AL

United Kingdom

Email: frf@st-and.ac.uk

\footnotetext{
* We are grateful to Atanas Christev for valuable discussions, and to seminar participants at Heriot Watt University, the 15th EALE Conference, Seville, and the University of Dundee, as well as two referees, for useful comments.
} 


\section{Introduction}

The positive correlation between firm or establishment size and wages is one of the most robust relationships in empirical economics, yet in spite of numerous studies, a generally accepted explanation has not yet emerged (Bayard and Troske, 1999; Winter-Ebmer and Zweimueller 1999, Manning 2003). While observed (and unobserved ) worker heterogeneity can account for some of the size-wage and productivity effects, the most promising explanation for the residual size effect seems to be the modern version of dynamic monopsony or upward sloping labour supply (Manning 2003, Mortensen 2003).

With realistic labour market frictions due to information and mobility costs, as well as heterogeneous worker preferences, the response of workers to job-vacancy announcements or wage changes will not be instantaneous, as in the extreme case of perfect competition and infinite wage elasticity. Employers thus generally have some market power even when many firms compete for labour in the same market. Manning (2003) has provided the first comprehensive development of the modern monopsony approach to labour markets, and shown that it explains many of the empirical findings that are

difficult to reconcile with the model of perfect competition. Boal and Ransom (1998) provide an introductory survey. Most of the development is based on a simple model of search by workers due to Burdett and Mortensen $(1989,1998)$, who derive a steady state wage distribution, with larger firms paying higher wages to identical workers, under the assumption that workers receive offers from all firms with equal probability.

Dynamic monopsony has received less attention, but Manning (2003) shows in a simple model that the firm's labour supply is less elastic in the short run than in the long run. This is quite intuitive even in a more realistic, spatial setting with firm and worker heterogeneity, because a firm or establishment that wants to expand employment rapidly at a particular location may need more new employees than the normal flow of job- seekers in the local labour market. Additional workers will have to be enticed away from other employers by higher pay offers, or compensated for longer travel or relocation. On the other hand, slow growth may be possible by just 
hiring the normal (random) flow of job - applicants without any wage increase, at least up to the point where replacement hiring just to maintain the establishment's labour force exceeds the normal flow of searchers in the local labour market at existing wages. At this point the pure static or long-run employer size - wage effect (ESWE) would become relevant, but can be usefully distinguished from the growth effect that reflects the short run elasticity. Thus firms that have recently grown rapidly are likely to pay higher wages than similar sized firms that have been contracting or stagnant, and the usual cross-section analysis will conflate these differing differentials. Declining employment is, of course, likely to put downward pressure on wages through the usual bargaining channels, as workers and their representatives moderate wage claims to protect jobs.

Here we provide some new evidence for upward sloping labour supply by including employment growth and decline in establishment wage estimates with a large panel of French firms. Since we do not have data on individual wages, we also control for occupational composition of the workforce. However the results do provide strong evidence that employment growth increases average wages (and decline reduces wages) conditional on lagged wages, size, human capital, and profitability or rent sharing. The long-run size - effect is actually enhanced when positive and negative employment growth is included, so that previous ESWE estimates without the growth variables may be biased in a manner that depends on the predominant direction and magnitude of prior employment change in the sample.

The obvious alternative hypothesis to dynamic monopsony would be the effect of exogenous shocks on marginal productivity, and hence on employment and wages in a competitive labour market. Since such shocks should also affect profitability it is clearly essential to control for this variable (in the absence of data on demand or other exogenous shocks) in order to distinguish between the competitive and monopsony hypotheses, as well as to account for rent- sharing and institutionalised profit -sharing in France.

The plan of the paper is to briefly discuss the theoretical background in Section 2, followed by the empirical specification in Section 3. The data used here are 
discussed in Section 4, and empirical results are summarised in Section 5, with conclusions in Section 6.

\section{Theoretical Background}

Models of individual search and wage setting firms used by Manning (2003), Mortensen (2003), and others are highly stylised but appealing because they yield strong results such as the ESWE with identical workers and firms in a steady state. Our firm panel allows us to control for the more complicated and asymmetric dynamics of expansion and contraction in estimation, but also requires consideration of the resulting changes in the composition of the workforce since we do not have individual data. Issues of employment change and asymmetry have been neglected in previous work based on the simple static or long- run ESWE and cross- sectional data $^{1}$.

Expanding firms generally prefer to hire younger workers at most levels, who require lower pay (due in part to lower seniority benefits), and offer greater flexibility and returns to training and experience. While we have not found any data on hiringage to support this, the anecdotal evidence is very strong. On the downside, to implement small reductions of the work force without incurring the costs of redundancy payment, it is common to simply stop hiring (younger) replacements for retiring older workers. Larger reductions can be achieved by encouraging early retirement, and even with competitive assumptions, average wages are likely to fall as employees with seniority benefits are lost and the average age of the workforce declines. $^{2}$ As in other EU countries, it is difficult to terminate older workers in France, who are usually on permanent contracts (CDI: Contrat a Durée Indéterminée). However, France has made more use of early retirement than most countries, and now has a participation rate for men aged 55 -65 of only about $45 \%$, compared to $50 \%$ in Germany and 65\% in the UK.

With realistic upward sloping labour supply, any rapid or substantial expansion is likely to require higher wages to attract workers from existing jobs and/or compensate for longer travel. Higher wages for new accessions then lead to matching demands by incumbent workers who are known to be concerned about 
relative wages and to value fairness and equity (Bewley, 1998; Fehr and Fischbacher, 2002). This effect should, at least to some degree, offset the wage - depressing influence of hiring younger workers during expansion. On the other hand, downsizing, even when mainly by early retirement, tends to reduce wage claims under any sort of bargaining in order to safeguard jobs, thus reinforcing the downward pressure on wages from changing age-composition. It follows that, with realistic frictions generating monopsony, the effects of positive and negative employment changes on average firm wages should be asymmetric. Employment reduction should unambiguously reduce average wages, while the effect of expansion should be smaller in absolute value, and could be positive if the (positive) monopsony effect dominates the (negative) age-composition effect.

It also follows that the usual cross - sectional regressions of wages on employer - size will give biased estimates of long run or steady state ESWE when firms have been growing or declining (rapidly) in periods just preceding the date of the cross-section. Manning (2003, pp.111-2) considers the estimation of short run and long run labour supply elasticity in cross - section with a model of 'dynamic monopsony', but his model specifies the wage to depend only on employment change, (without distinguishing between positive and negative changes), and lagged employment, and omits the lagged dependent variable that is usually required for fully dynamic panel estimation. ${ }^{3}$ No empirical results are reported for this specification. When employment change is not divided into its positive and negative components, evidence on monopsony from the effects of expansion (the positive component) may be biased.

Earlier, Manning (2003, p.88) does refer to panel estimates of labour supply elasticity, where wage growth is regressed on employer size growth and individual controls. However this approach does not distinguish between the short run effect of employment change and the long run, size effect. Furthermore, the data only provide worker responses to the employer size question, "which are likely to have a lot of measurement error”, and thus lead to underestimation of the size-wage effect.

Unobserved worker quality differences have also been suggested as an explanation for the ESWE, and firms that maintain a wage differential (as required for a period of rapid expansion) that is larger than the differential needed for constant 
employment of a given quality, are of course likely to attract 'better' workers in some, possibly unobserved, dimension. A direct analysis of individual movements between different size classes of (small and medium- sized) Swiss firms by Winter-Ebmer and Zweimueller (1999) shows that individuals capture about half the (OLS) size -wage differential when moving either to a larger or to a smaller firm. Brown and Medoff (1989) obtain similar results for the U.S. This leaves a substantial firm effect that cannot be explained by worker heterogeneity, but is consistent with the monopsony model $^{4}$.

Our restriction to firm level data and average wages obviously means that we cannot identify individual labour supply elasticities precisely, while the (age-) composition of the work force is changing. However we do report short - and long run firm elasticities to check how they compare with existing results. The data does provide accurate establishment size - and profitability - measures, of the kind that are missing in the individual survey data used by Manning and others. Thus, as outlined above, we can provide some evidence for upward sloping labour supply in a dynamic panel in the unionised French labour market, (which thus differs from the non bargaining context of wage - setting firms used by Manning (2003)). As already noted, we distinguish between positive and negative employment change. A positive estimated net effect of positive employment growth on wage growth means that the short run (positive) supply effect dominates the negative age- composition effect. Such a positive (net) effect would provide clear evidence of upward sloping labour supply in the presence of our profitability control variable. Somewhat weaker evidence could be provided even if the negative composition effect dominated but the absolute value of the expansion effect was much less than that of contraction.

Such results might be explained by demand and productivity shocks in a competitive model (Blanchflower, Oswald and Sanfey, 1996, Theoretical appendix), but expansion should then be accompanied by higher profitability as well as wages, so it is important to control for some measure of profits when testing the monopsony hypothesis. Temporary demand shocks are usually met with increased overtime working at premium rates, which raises average wage rates, independently of long run labour supply to the firm. With a longer time horizon, firms may expand employment to increase market share in anticipation of higher future profits, which would not 
require wage rises in a competitive labour market. Similarly, a permanent shock to one firm in a competitive labour market should lead to higher employment and profit at the market wage, rather than higher wages. In addition, rent-sharing is itself a widely observed consequence of imperfect competition. Although we do not have data on working time and overtime pay, our profit measure should also provide a proxy for the intensity of use of both capital and labour, and thus control to some extent for the effects of increased overtime at premium rates on average wages following temporary shocks.

On the other hand, the age-composition effect of declining employment or negative growth adds to the downward pressure on wages in bargaining, and thus the absolute value of the total effect should be larger than the positive effect of positive growth. These two results of downsizing cannot, however, be distinguished to provide evidence for monopsony, because the age -composition effect would remain even in a perfectly competitive labour market. Clearly it would be necessary to match individual with firm level data in order to identify and separate the age composition and monopsony effects.

Finally it should be emphasized that the coverage of most workers in France by collective bargaining, as well as generous minimum wages, is likely to raise the pay of the less qualified (wage compression), and increase their unemployment, with resulting job-rationing and queuing. Strictly speaking, we thus cannot identify the standard labour supply curve. Queuing should reduce the observed wage employment elasticity, making it more difficult to detect upward sloping labour supply than in largely non-unionised UK or US labour markets.

\section{Empirical Specification}

Our basic specification of the determinants of average earnings is defined as follows:

$$
W_{i t}=\alpha_{0}+\alpha_{1} W_{i t-1}+\alpha_{2} \text { pos.emp.change }+\alpha_{3} \text { neg.emp.change }+\alpha_{4} \text { empl }+ \text { controls }+ \text { error }- \text { term }
$$

where $W_{\text {it }}$ is the log average wage per employee in firm $i$ at time $t$.

As a measure of size we use the standard log of lagged employment, written as $L(-1)$.

One reason for using the lagged wage is that existing workers’ wages take time to 
catch up with any extra pay for new hires. Other reasons are to reduce endogeneity problems and provide comparison with existing size-wage elasticity estimates, and also because our results were more stable with lagged employment).This follows Manning's (2003, p.112) theoretical model of short-run and long-run elasticities, which is not, however a dynamic model with a lagged dependent variable, but only refers to cross-sectional estimation. We also use a set of dummy variables for different size categories, which improve results in some respects. For the employment change we use the change of log employment over 2 years, $L-L(-2)$, divided into positive and negative components as discussed above. We use the absolute value of the latter, so that employment declines have negative effects. The two-year change smoothes out minor fluctuations and gives somewhat better results than annual changes. The most interesting control that we have emphasized in the theoretical discussion is a measure of profitability, for which we use average operating income over the current and previous years. This gross measure avoids managerial and accounting discretion and probably best captures the employer's ability to pay. Other controls include a set of human capital proxies describing the occupational composition of the labour- force, as well as the female share, industry dummies and time dummies. These shares only change slowly over time and are only crude proxies for human capital and occupation productivity, so as usual in dynamic wage estimation we adopt a partial - adjustment model by including the lagged dependent variable, which is omitted in Manning’s (2003, p.112) model.

To estimate this wage function, we tried several estimators (OLS, fixed effects, random effects and Generalised Method of Moments or GMM) but we report only GMM-system estimates, which allow for possible endogeneity of independent variables such as profit and employment change, and an OLS model for comparison. Standard GMM estimators use variables in differences, to eliminate unobservable individual effects, and use lagged values (in levels) as instruments to correct for simultaneity bias. However, as emphasized by Griliches and Mairesse (1997), fixed effects and GMM estimators produce rather unsatisfactory results when the correlation between variables in differences and their level is weak. Precisely this problem arises with our occupational shares, which only change slowly over time. Blundell and Bond $(1998,1999)$ show that the lagged levels of a series provide weak instruments for first differences, and these instruments are less informative when the 
coefficient of the lagged endogenous variable is large. This is again relevant in our case, where the lagged wage probably captures most of the human capital and age variation in the presence of occupational shares that are only rather crude proxies. They suggest taking into account additional non-linear moment conditions which correspond to adding (T-2) equations in levels with variables in differences as instruments ${ }^{5}$ (Arellano and Bover, 1995), and this is the System-Gmm Estimator.

We usually report two -step estimates instead of the first step estimates, because the latter are preferable when the number of individuals (firms) is small (when standard errors are underestimated; Bond, Bowsher and Windmeijer, 2002), and this does not apply in our case. In our most complete, preferred specification we also report the one step estimate, to verify that the second step estimates do not differ much from the one step. We note that they are robust to heteroskedasticity and/or to autocorrelation (Arellano and Honoré, 2000).

\section{Data Description}

Our data come from a large sample of French firms observed from 1986 to 1996. The sample is derived from two surveys conducted by INSEE (Institut National de Statistiques et des Etudes Economiques): EAE and ESE. The EAE (Enquête Annuelle d'Entreprises) is an annual firm- level survey that provides information on profit, employment, wages, capital and a sixteen digit industrial affiliation. ESE (Enquête Structure des Emplois) is an annual establishment survey on the structure of employment by qualification and gender (available for the period 1986-1996). The very detailed qualifications data have been regrouped into 6 categories (TOP: for top managers, RD for researchers, MID: middle qualification, WH : white collar, BS : Blue skilled and BU for blue unskilled). Merging the two sources provides more then 10.000 firms, but does not provide separate establishment data for multi-establishment firms. Since the theoretical case for monopsony summarised in Section 2 really applies to establishments at a particular location, rather than to total employment in a number of establishments, we select only single-establishment firms with at most one year of missing data to obtain more then 6,000 establishments. 
The first Table, 1, reports descriptive statistics for the main variables and their sources. Annual wages and profits per employee are measured in 1000FF, and show considerable heterogeneity between firms. Profitability is measured as the average Operating Income (OI) per employee for the current and previous year. When we split the sample into large and small firms, mean wages are - surprisingly - slightly lower in large firms, while operating income is higher. Establishment size varies from 12 to nine thousand (8851) employees. Over the decade, employment change is almost zero, due to positive average growth from 1986-90, and an offsetting decline from 1990-96. Except for more skilled blue collars and fewer females in small firms where the difference is important, the composition of the workforce seems to be similar in both samples. Average employment change is slightly bigger in large firms.

Finally it should be emphasized that although only about 9\% percent of the French workforce is unionised, most workers are covered by industry - level collective bargaining, sometimes with additional firm-level bargaining. There is a legislated minimum wage (SMIC) and cost-of-living increases. Most workers receive more than the minimum, and since we use average wages in the establishment, this minimum has little relevance. Wage inequality is less than in the UK, and unemployment, particularly among young workers, is higher, so as discussed above, estimated labour supply elasticities in a 'rationed' market will probably be biased upwards.

\section{Empirical Results}

The first results for large establishments with over 50 employees are reported in Table 2. The most basic specification in Model 1 omits operating income (OI) and employment change, but includes all the other controls for occupation, industry, and time that are used throughout. The effect of size (lagged employment) is insignificantly different from zero. Model 2 then adds OI, which is just significant, while the ESWE remains negligible. In model 3, negative and positive employment change are added to the basic specification of Model 1, and turn out to be highly significant. As discussed in Section 2, the positive coefficient of positive employment change is consistent with monopsony, and the much larger coefficient (in absolute value) of negative growth follows our theoretical prediction ${ }^{6}$, even if the difference 
between these coefficients turned out to be insignificant at the standard levels. Controlling for profitability (OI) in Model 4 only slightly reduces the effect of positive employment growth, but greatly strengthens the case for dynamic monopsony as explained above. To allow for negative OI we do not use the log of this variable, so the coefficients are not elasticities. Interestingly, the standard, ESWE from the coefficient of lagged employment now becomes highly significant in Models 3 and 4, with an elasticity of about 0.02 . Of course, in the context of our partial - adjustment panel model, this is only the short run estimate of the long-term size effect, which is about 5 times as large, or about 0.1 .

The lagged dependent variable, $W(-1)$, in our specification is very precisely estimated with a coefficient of about 0.8 , and a t-test shows that this value is significantly different from unity. Of course, the presence of the lagged dependent means that our specification is equivalent to an estimate of wage growth that is negatively related to the magnitude of the lagged wage. The controls for occupation and female share are all significant with expected signs, but are not reported to save space. Unreported regressions without the lagged dependent variable resulted in unsatisfactory dynamics and diagnostics.

In Table 4 (see appendix) we introduce 3 size dummies in place of the continuous variable $L(-1)$. L100200 indicates establishments with between 100 and 200 employees; L200300 stands for the 200 to 300 range, and L300 for more than 300 workers. All are highly significant. Using the same specifications otherwise, the main difference to Table 2 is that our OI measure of profitability is significant in each case, with a much larger coefficient than in Table 2, and substantially reduces the magnitude of the negative employment change coefficient in Model 4. The employment change effects are slightly smaller than the corresponding coefficients in Table 2, but also highly significant, and the difference between positive and negative employment change is now highly significant (for model 3). The results in Table 4 suggest that dummy variables are in some ways a more satisfactory method of controlling for the static or long - run ESWE than the customary use of continuous size measures, but they do have the disadvantage of not allowing us to calculate a simple size-wage elasticity. 
The final column in each table reports the one - step GMM estimates of our most comprehensive specification in Model 4. Though there are some changes in the coefficient sizes, so that employment growth and decline now (rather implausibly) have effects of similar absolute magnitude, significance levels ( $\mathrm{t}$ - statistics) of the crucial positive employment change variable are very similar. Lower significance levels of the negative employment change effect are not particularly plausible. In any case, our main results seem to be robust with respect to these estimation procedures. While lagged employment loses significance in the one-step estimate in Table 2, we note that an unreported one-step estimate of Model 4 in the Appendix preserves highly significant size dummies. Finally, a Wald test for the joint significance of the parameters (not reported here) always rejects the null hypothesis.

In Table 3 the estimates for the sample of small establishments with less than 50 employees are reported. While most results are similar to the large firm sample, positive employment expansion effects lose statistical significance (but the difference is still insignificant at the standard levels). While this is perhaps not surprising, since small establishments should have less of an impact on their local labour markets, it should be emphasised that a significantly negative age - composition effect would be expected under perfectly competitive conditions. Thus even imprecisely estimated, non - negative coefficients for expansion while controlling for profitability gives some support to the dynamic monopsony theory.

Finally we observe highly significant, long-run size - wage effects in almost all specifications, in both samples. Since our lagged dependent variable should control for worker quality and compensating differentials more effectively than usual measures of human capital, this suggests that larger establishments really do have to pay higher wages just to maintain a work - force of given quality, which is the main conclusion of existing, static monopsony models. These estimates do not change much across various specifications, probably because there is little change in firm size on average in our panel. Our theory and results suggest that in samples with substantial overall growth or decline the long-run ESWE would be biased in the absence of controls for employment change. 
Employment growth has a strong and robust, positive effect on average wages in large establishments, in spite of the likely negative composition effect, with many controls for human capital, firm size and other relevant variables. The long - run labour -supply elasticity of average wages, from Model 4 in Table 2, is calculated to be 0.103, (with a t-statistic of 3.1), which is much greater than Manning's (2003, pp.87-88) results from different IV specifications that do not appear to include the lagged wage, and which he suggests are underestimates. Our results from employment expansion, with a short - run elasticity ranging from 0.04-0.06, provide further evidence against the perfectly competitive model of the labour market because expansion by hiring generally younger workers at competitive wages should reduce rather than raise average wages. Our use of the lagged dependent variable means that it is difficult to invoke unobserved employee characteristics as an explanation for the ESWE. Finally, if productivity and demand shocks were driving both wages and growth in a competitive market, then this should be captured by our profitability control, and the independent positive effect of employment expansion on wages is hard to explain.

\section{Conclusions}

We have examined the ESWE in the context of dynamic panel estimation of average firm wages in a large sample of French firms, where the lagged dependent variable should control for those employee characteristics that are not usually observed in studies of individual workers. Both employment and employment growth turn out to be robustly and strongly related to wage (- growth) in the sample of large firms (establishments) with over 50 employees, and the positive effect of expansion, smaller in (absolute) magnitude than the negative effect of contraction, are consistent with the upward sloping labour supply curve of modern, dynamic monopsony theory. Our control for profit per employee has a highly significant, positive effect on wages (-growth), which is consistent with many other studies that find rent sharing, and

essentially excludes competitive explanations of the ESWE based on productivity shocks.

As might be expected, the evidence for monopsony is weaker in the small- firm sample of establishments with less than 50 workers. However, the fact that the 
coefficients of employment expansion are similar - sized and positive, though not significant at conventional levels, still offers some indication of monopsony in contrast to the expected competitive result of a significant negative, age composition effect of employment expansion on average wages.

Overall, there is strong evidence both for the long-run ESWE, and the dynamic, short run effect of employment expansion, both of which suggest upward sloping labour supply since temporary shocks or unobserved worker quality cannot plausibly explain the results in the presence of lagged wages and controls for profit. 


\section{References}

Aboud, J. M., F. Kramarz, and D. N. Margolis, (1999), "High Wage Workers and High Wage Firms”, Econometrica, 67, 251-333.

Arellano, M. and Bover, O. (1995), "Another look at the instrumental-variable estimation of error-components models", Journal of Econometrics, 68: 29-52.

Arellano M. and B. Honoré, (2000), "Panel data models : some recent developments”, Working Paper No. 0016, CEMFI, Nov.

Bayard, K. and K. R. Troske, (May 1999), "Examining the Employer- Size Wage Premium in the Manufacturing, Retail Trade, and Service Industries”, Am. Econ. Rev., 89, 99-103.

Bewley, T. F., (1998), “Why not Cut Pay?”, European Econ. Rev., 42, 459-90.

Blundell, R. and Bond, S. (1998), "Initial conditions and moment restrictions in dynamic panel data models", Journal of Econometrics, 87: 115-145.

Blundell, R. and Bond, S. (1999), “GMM estimation with persistent panel data : an application to production function”, Working paper W99/4, The Institute for Fiscal Studies.

Bond S., Bowsher C. and F. Windmeijer, (2002), “Criterion-based inference for Gmm in autoregressive panel data models”, WP 01/02, Institute for Fiscal Studies.

Blanchflower, D.G., A.Oswald and P.Sanfey, (1996) "Wage, Profits and Rent Sharing", Quart. J. of Econ., 111.

Boal, W.M. and M.R. Ransom, (1997), "Monopsony in the Labour Market", J. of Econ. Lit., 35, March, 86-112.

Brown, C. and J. Medoff, (1989), “The Employer Size-Wage Effect”, J. of Pol. Econ., 97, 1027-59.

Burdett, K. and D.T. Mortensen, (1989), "Equilibrium Wage Differentials and Employer Size”, Disc. Paper 860, Northwestern University.

Burdett, K. and D.T. Mortensen, (1998), "Wage Differentials, Employer Size and Unemployment", Int. Econ. Rev., 39, May ,257-73.

Burgess, S., J. Lane and D. Stevens, (2000), “Job Flows, Worker Flows and Churning”, J. of Lab. Econ., 18, July, 473-502. 
Christev. A and F. R. FitzRoy, (2002),. "Employment and Wage Adjustment: InsiderOutsider Control in a Polish Privatization Panel Study”, J. of Comparative Economics, 30, $251-75$

Fehr, E. and U. Fischbacher, (2002), "Why Social Preferences matter”, Economic Journal, 112, C1-34

Green F., S. Machin, and A.Manning, (1996), "The Employer-size Wage Effect: Can Dynamic Monopsony Provide an Explanation?”, Oxford Economic Papers, 433-53.

Griliches, Z. and Mairesse, J. (1997), "Production functions: The search for identification", in S. Strom (ed.), Essays in Honour of Ragnar Frisch, Econometric Society Monograph D series, Cambridge: Cambridge University Press.

Haltiwanger, J. C., J.I. Lane and J. R. Spletzer, (1999), "Productivity Differences Across Employers: The Roles of Employer Size, Age and Human Capital”, A.E.R. Papers and Proceedings, 89, May, 94-98

Manning, A., Monopsony in Motion, (2003), Princeton University Press, Princeton and Oxford

Mortensen, D. T., (2003), Wage Dispersion, Cambridge, Mass., MIT Press

Winter-Ebmer, R. and J. Zweimueller, (1999), "Firm-Size wage Differentials in Switzerland: Evidence from Job-Changers”, Am. Econ. Rev. Papers and Proceedings, 89, May, 89-93. 
Table 1 : Descriptive Statistics

\begin{tabular}{|c|c|c|c|c|}
\hline & \multicolumn{2}{|c|}{$\begin{array}{l}\text { Large firms : more than } 50 \\
\text { (30434 obs, } 3106 \text { firms) }\end{array}$} & \multicolumn{2}{|c|}{$\begin{array}{l}\text { Small firms : less than } 51 \\
\text { (35173 obs, } 3596 \text { Firms) }\end{array}$} \\
\hline & Mean & Std. Dev. & Mean & Std. Dev. \\
\hline Source : EAE & & & & \\
\hline Wage & 116.585 & 26.70 & 118.952 & 30.01 \\
\hline Op, Income & 112.411 & 91.04 & 91.701 & 83.72 \\
\hline Size & 145.267 & 226.61 & 37.790 & 12.86 \\
\hline Emp, Change & 0.028 & 0.19 & -0.010 & 0.19 \\
\hline Pos emp change & 0.149 & 0.16 & 0.138 & 0.13 \\
\hline Neg emp change & -0.118 & 0.13 & -0.150 & 0.15 \\
\hline Source : ESE & & & & \\
\hline Female : FEM & 0.314 & 0.25 & 0.282 & 0.24 \\
\hline Top manag. TOP & 0.072 & 0.05 & 0.082 & 0.06 \\
\hline R\&D & 0.011 & 0.02 & 0.009 & 0.02 \\
\hline White collar : WH & 0.078 & 0.06 & 0.074 & 0.06 \\
\hline Blue Skilled : BS & 0.455 & 0.22 & 0.508 & 0.23 \\
\hline Blue Unskil. : BU & 0.254 & 0.23 & 0.218 & 0.23 \\
\hline
\end{tabular}


Table 2 : Large firms, (more than 50 employees)

Dep. variable : Log average earnings per head, 2 step Sys-Gmm estimates

\begin{tabular}{|c|c|c|c|c|c|}
\hline & Model 1 & Model 2 & Model 3 & Model 4 & $\begin{array}{l}\text { Model } 4 \\
\text { One Step }\end{array}$ \\
\hline Constant & $\begin{array}{l}0.735 \\
(3.89)\end{array}$ & $\begin{array}{l}0.856 \\
(4.62)\end{array}$ & $\begin{array}{l}0.841 \\
(5.24)\end{array}$ & $\begin{array}{l}0.847 \\
(6.33)\end{array}$ & $\begin{array}{l}1.131 \\
(5.95)\end{array}$ \\
\hline$W(-1)$ & $\begin{array}{l}0.838 \\
(20.30)\end{array}$ & $\begin{array}{l}0.807 \\
(20.00)\end{array}$ & $\begin{array}{l}0.789 \\
(22.10)\end{array}$ & $\begin{array}{l}0.792 \\
(26.60)\end{array}$ & $\begin{array}{l}0.732 \\
(17.5)\end{array}$ \\
\hline Size : L(-1) & $\begin{array}{l}0.001 \\
(0.15)\end{array}$ & $\begin{array}{l}0.004 \\
(0.48)\end{array}$ & $\begin{array}{l}0.026 \\
(3.42)\end{array}$ & $\begin{array}{l}0.021 \\
(3.21)\end{array}$ & $\begin{array}{l}0.012 \\
(1.23)\end{array}$ \\
\hline $\begin{array}{l}\text { Op Income: } \\
\text { O.I }\end{array}$ & & $\begin{array}{l}0.004 \\
(1.86)\end{array}$ & & $\begin{array}{l}0.006 \\
(1.48)\end{array}$ & $\begin{array}{l}0.013 \\
(2.15)\end{array}$ \\
\hline Neg. Emp & & & -0.099 & -0.088 & -0.069 \\
\hline Change & & & $(4.65)$ & (3.80) & $(1.86)$ \\
\hline Pos Emp & & & 0.057 & 0.051 & 0.060 \\
\hline Change & & & $(4.41)$ & $(4.32)$ & $(3.40)$ \\
\hline Obs & 27328 & 27140 & 27140 & 27140 & \\
\hline Sargan & [0.664] & [0.545] & [0.906] & [0.942] & \\
\hline $\operatorname{AR}(2)$ & -0.374 & 0.346 & 0.993 & 0.62 & \\
\hline $\begin{array}{l}\text { Long Run } \\
\text { Size effects }\end{array}$ & N.S & N.S & $\begin{array}{l}0.124 \\
(3.18)\end{array}$ & $\begin{array}{l}0.103 \\
(3.10)\end{array}$ & \\
\hline
\end{tabular}

In all specifications, the female rate, 5 occupational category, 14 industry dummies as well as time dummies are included. We also tried the interaction between industry dummies and time dummies without change in results.

Diagnostics included : T statistic, Sargan P-value for the validity of the instruments, and a second order autocorrelation test (normally distributed).

Instruments used for differenced equations : from the first to the fourth lags for skills, female, employment change, from the second to the fourth lag for employment and from the third to the fourth lag for wages. For equation in levels we used differenced variables as instruments as follow: the first lag for skills, female and employment changes, the second lag for employment and the third lag for wages. 
Table 3 : Small firms, (less than 51 employees)

Dependant variable : Log average earnings per head, 2 step Sys-Gmm estimates

\begin{tabular}{|c|c|c|c|c|}
\hline & Model 1 & Model 2 & Model3 & Model 4 \\
\hline Constant & $\begin{array}{l}0.638 \\
(4.16)\end{array}$ & $\begin{array}{l}0.696 \\
(4.12)\end{array}$ & $\begin{array}{l}1.089 \\
(7.15)\end{array}$ & $\begin{array}{l}0.855 \\
(4.91)\end{array}$ \\
\hline$W(-1)$ & $\begin{array}{l}0.872 \\
(27.90)\end{array}$ & $\begin{array}{l}0.797 \\
(24.90)\end{array}$ & $\begin{array}{l}0.761 \\
(22.60)\end{array}$ & $\begin{array}{l}0.769 \\
(23.40)\end{array}$ \\
\hline $\mathrm{L}(-1)$ & $\begin{array}{c}-0.013 \\
(0.64)\end{array}$ & $\begin{array}{l}0.066 \\
(3.53)\end{array}$ & & $\begin{array}{l}0.055 \\
(2.89)\end{array}$ \\
\hline Op Income & & & $\begin{array}{l}0.029 \\
(2.66)\end{array}$ & $\begin{array}{l}0.014 \\
(2.91)\end{array}$ \\
\hline Neg. Emp & & -0.105 & -0.110 & -0.097 \\
\hline Change & & (3.42) & (3.61) & (3.12) \\
\hline Pos Emp & & 0.043 & 0.064 & 0.045 \\
\hline Change & & (1.24) & (1.71) & (1.31) \\
\hline Obs. & 31577 & 31314 & 31314 & 31314 \\
\hline Sargan & [0.779] & [0.526] & [0.575] & [0.511] \\
\hline $\mathrm{AR}(2)$ & -1.426 & 1.285 & 1.263 & 1.554 \\
\hline Long Run L & NS & $\begin{array}{l}0.312 \\
(2.87)\end{array}$ & & $\begin{array}{l}0.226 \\
(2.46)\end{array}$ \\
\hline
\end{tabular}




\section{APPENDIX}

Table 4 : Large firms, (more than 50 employees)

Dep. variable : Log average earnings per head, 2 step Sys-Gmm estimates

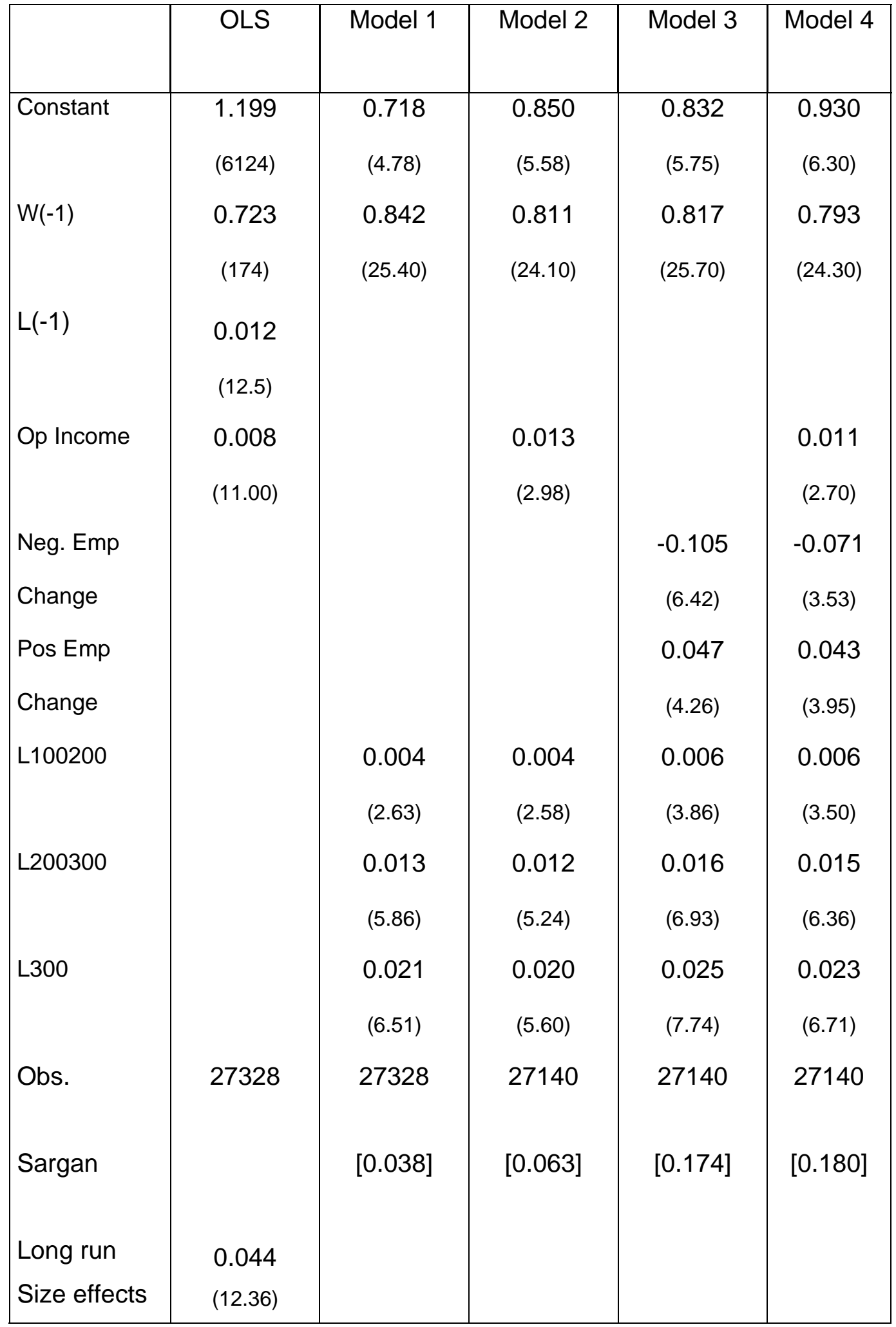


${ }^{1}$ Christev and FitzRoy (2002) find some evidence of asymmetry in a Polish privatisation panel.

${ }^{2}$ Even contracting firms continue to hire vital replacements, and expanding firms may lose employees for various reasons as well as retirement (Burgess, Lane and Stevens, 2000). These largely random movements should not in general affect the systematic changes in composition discussed above.

${ }^{3}$ Manning (2003a) finds evidence that wages for similar workers increase with commuting distance. ${ }^{4}$ Abowd et al (1999) consider transitions between firms but assume them to be exogenous, thus missing the distinction between quits and terminations, though the latter generally lead to substantial wage reductions.

${ }^{5} \mathrm{~T}-2$ equations coming from the moment restriction: $\mathrm{E}\left(\varepsilon_{\mathrm{it}} \Delta \varepsilon_{\mathrm{it}-1}\right)=0$, where $\mathrm{T}$ is the number of years the firm is represented in the sample.

${ }^{6}$ Major downsizing involving involuntary redundancy is likely to affect younger workers with less seniority protection, but this is less common than voluntary redundancy in the form of early retirement for older and higher paid workers. 